\title{
Zeitgeist through the Eyes of Felipe P. De Leon (1912-1992) Musical Nationalism and the Cultural Environment of the 1930s
}

\author{
Renato B. Lucas \\ University of Santo Tomas
}

\section{Abstract}

Zeitgeist in this article is a reconstruction of an era built from historical accounts that lead toward and around Felipe P. De Leon-reconstructing and interpreting his ideas regarding that which could be extrapolated through his musical works, writings, and campaign for cultural literacy. De Leon echoes "the general intellectual, moral, and cultural climate of an era" of the 1930s. A significant side of De Leon is his sense of history seen through his chronicles of musical events and his various views and perceptions of the Filipino audience's reception. His writings, his musical expressions, and his interactions with fellow artists coagulate with a certain degree of interdisciplinarity to reflect the spirit of the era. Reconstructing the zeitgeist considers the tensions that exist between music histories (the practice of music such as performances) vis-à-vis music theories (the concept or constructs of tone engineering in terms of context). As articulated by Weber in "Beyond Zeitgeist: Recent Work in Music History" (1994) and seen through the eyes of De Leon, nationalists are concerned then at creating an inclusive culture, weaving a web of meaning that 
unites the sometimes splintered populace by asserting cultural independence during the politically volatile 1930s.

\section{Keywords}

cultural, cultural environment, musical expressions, reconstruction, zeitgeist 


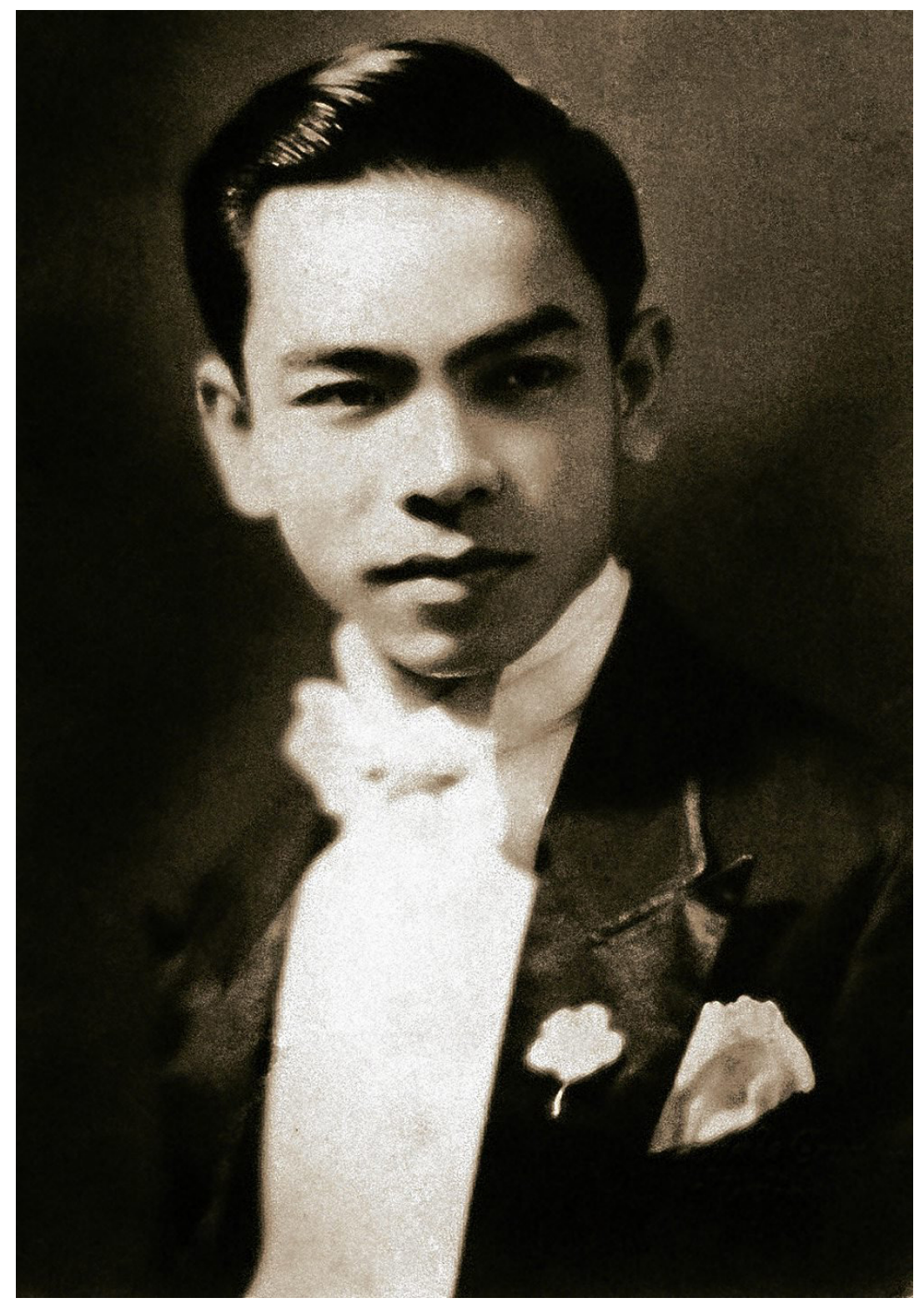

Fig. 1 Felipe Padilla de León was a Filipino classical music composer, conductor, and scholar, http://en.wikipilipinas.org/ 
Felipe Padilla De Leon, Sr. (1912-1992), posthumously bestowed the National Artist for Music Award in 1997 and known for his popular Christmas carols such as Pasko Na Naman and Payapang Daigdig, lived a long life extensive enough to witness the unraveling of eight decades in Philippine history. He was born after the beginning of the twentieth century and died eight years before the next century. His lifetime spanned various periods of Philippine history with crisscrossing layers of narratives on cultural, social, and political history. His life-work focus was on musical nationalism within the background of the Filipino's quest for recognition in all aspects of the nation's existence-economic, socio-political and, most importantly for him, cultural. This particular period in Philippine cultural history shall be looked into through the lenses of the Maestro's life.

Zeitgeist here shall be borrowed to mean two things: first, a reconstruction of an era built from historical accounts that lead toward and around De Leon; and second, a reconstruction and an interpretation of De Leon's ideas regarding that which could be extrapolated through the ideas behind his musical works, writings, and campaign for cultural literacy. De Leon echoes how the Merriam-Webster Unabridged Dictionary defines zeitgeist as "the general intellectual, moral, and cultural climate of an era.”

Political eras shall just serve as chronological markers or time frame references. For example, by 1934, the American Congress had passed the Tydings-McDuffie Law granting independence to the Philippines after a period of ten years. The law preceded by the Jones Law of 1916 aimed to establish a stable government with the transfer of political power from the Americans to the Filipinos. It was a marred negotiation as the American colonizers laid down the rules to the detriment of the Filipino interests. In the midst of the lopsided agreement between the Filipinos and the Americans, a politically-charged era of asserting Filipino nationhood ensued. With the uneven political and economic negotiations, the cultural component of Filipino nationalism must have been the only non-negotiable component left.

Cultural nationalism through musical nationalism has been the crux of De Leon's life. His ideas, incubated at an early age, surfaced in the 1930s. 
De Leon, as a composer, has become a historical agent chronicling his own experience and the collective experiences of the times.

\section{Academized Art and Nationalist Expressions}

There are at least three kinds of experience in artistic creation. First is the artist's, which he aims to communicate; second is the objectification of the experience or the process of creating the work of art; and lastly is the gratifying experience of having produced a significant work (Ortiz 9). Another kind of experience related to art is that evoked in the perceiver of the workbe it a song, a painting, or a play.

The community of artists in the 1930s found diverse media in expressing nationalism through their various disciplines, whether they be writers, composers, painters, actors, and so forth. It was an era ripe for a consolidation of the "commonwealth of the arts," to borrow the title of Curt Sachs's 1946 book, in facing the challenges of the 1930s on how to define a nation. It was an era when so many artists began expressing their ideals recognizing their commonality and diversity in expressing one's culture and shielding it from the threat of American colonial cultural impositions.

Even though American stewardship was a lopsided deal, particularly the political and economic components at recognizing Philippine independence, the reactions were quite extensive in the cultural aspect. The need to define what is "Filipino" bloomed and inspired a call for action from the artists. By the 1930s, the fruits resulting from the introduction of formal training were ripe. It facilitated articulateness in artistic expressions. Paraphrasing Teodoro Agoncillo, it was an era reminiscent of the earlier century's continuing "self-assertion of becoming" (Hila 34). The idealization turned into action.

\section{Filipinism Shield and Jorge Bocobo}

With the growing concern over the stark contrast in the changing political environment of Americanization or imposition of cultural hegemony vis-à-vis the flames of nationalism, cultural practices like music served as a potent medium for shielding the thin layer of Filipinism, or Filipino cultural 
nationalism, for concerned artists like De Leon. Resil Mojares, in a concise statement, said, "[n]ationalism was the dominant discourse in the first quarter of the century" (17). This cannot be overemphasized enough because similar to what was happening in many regions of the country, an artistic explosion of zarzuela productions came about as mentioned in the works of Patajo-Legasto (2000) and Tiongson (1986).

Mojares also wrote that early twentieth-century Filipinism was defensive, revivalist, and reactive to the advance of Anglo-Saxonization. Anxieties over the inroads of foreign influence fueled an interest in the preservation of local and indigenous traditions. It was not until the Commonwealth period that Filipinos took over the leadership of Public Instruction with the likes of Sergio Osmeña and Jorge Bocobo (9). During his incumbency as University of the Philippines President from 1934 to 1939, Jorge Bocobo (1886-1965), initiated what could be termed as the Filipinism shield. Bocobo took concrete action and launched a nationwide research project on dance and music, led by Francesca Aquino (1899-1983) and Antonino Buenaventura (1904-1996). Both artists would eventually be bestowed the National Artist Award for Dance and Music, respectively. These research endeavors on the part of the state university pioneered in the work of documenting and preserving vast cultural heritage of oral tradition.

In the whirlwind of nationalistic expressions of the 1930s, De Leon was caught between utilizing folk materials (songs, dances) and adopting the newly acquired Western classical music idioms and traditions. He then decided to appropriate Western classical tradition while retaining much of the popular or native traditions.

De Leon was instrumental in concretizing the ideals in what Benjamin Curtis calls "the making of the (Filipino) nation" in his Music Makes the Nation: Nationalist Composers and Nation Building in the Nineteenth-Century Europe (2008). The 1930s were dynamic years of cultural nationalism. Contemporary fellow artists in the various artistic disciplines, whether in literature, the visual arts, or the theater, were active in sustaining the momentum of the era. 


\section{The Theatrical Arts}

Philippine theater, for example, illustrated nationalistic assertions. Clearly exhausted from the efforts since the Philippine Revolution, the American authorities posed a very serious challenge. About them, Agoncillo wrote:

In 1901, they passed the Sedition Law, which made uttering seditious works, delivering speeches, and publishing works that contained libelous remarks against the US government a crime. Despite the threat of imprisonment, some dramatists presented a number of "seditious plays" (22).

Referring to the work of these dramatists, Nicanor Tiongson wrote:

With the 'seditious' dramas, for the first time, one encounters a true and disturbing representation of the Filipino struggle against the Spanish and American colonizers. Here one finds plays, which sought to enlighten and exhort the masses to support the revolutionary movement based in the mountains, and thus prevent colonization by another Western power (Tuklas Sining 85).

Music, too, and other artistic endeavors became the medium of resistance to the cultural imperialist. The American occupation constituted a radical paradigm shift affecting the social and cultural life of the Filipinos. Although cultural policies seemed benign or not causing immediate damage, "cultural imperialism" was a major concern then. In the Philippine education system, for example, Raul Navarro pointed out that "[m] usic education (primary and secondary school) has been utilized as a major component in the cultural homogenization or Americanization of Filipinos" (1). Music was utilized to proselytize the merits of Americanization. Songs about things that were beyond the common reach of ordinary school child (e.g., snow, white Christmas, Halloween, and other things peculiar to American cultural practices) were sung. There was enough reason for concern.

At the turn of the twentieth century, the prevailing practices concerning musical art forms, except the liturgical, encompassed theatrical performances such as operas. There were secular localized performances and other forms of social gatherings for a performance like the tertulia (house concerts). The 
perceived threat of losing one's being a Filipino was a grave concern of the times. The inclusion of formal music training as introduced in the American education system at the University of the Philippines (Conservatory of Music established in 1916) and by the earlier German Benedictine Tutzig sisters at St. Scholastica's College (Conservatory of Music established in 1907) were novelties, for these new opportunities augmented means of cultural expressions beyond entertainment and folk, traditional, or indigenous music. De Leon has been described as:

one the most prolific composer[s] of musical masterpieces that express the Filipino nation's ideals, historical experiences and glorious destiny. For his immense contribution to the cultural advancement of his country, he may well be considered the greatest Filipino composer of the post-war era, and certainly the most well-known. De Leon did not spare any vehicle-musical, literary, print and broadcast media, academic, civic or governmental-to fulfill his unwavering commitment to the development of Philippine music and its appreciation by our people, promotion of nationalism and advancement of the Filipino musician's welfare (Beltran 111).

Very few artists in Philippine history have been accorded a patriotic citation. Prominent musicians are held in high esteem either for their superb performances or original works, but are seldom acknowledged for their campaign towards nationalism. Earlier recognized musicians in history were Marcelo Adonay and Julian Felipe. Heroism has always been attributed to successes in frontal warfare. Jose Rizal is one of the exceptions, as explicated by Renato Constantino in his landmark lecture, Veneration Without Understanding (1969). Nationalistic endeavors, mostly deeds with political implications, are the usual considerations of historical significance. There seems to be a huge gap in the portraiture of artists' contribution to nation building. Subsequently, a few musicians were conferred the National Artist title not just for their artistic output but also for their artistic philosophies as fruitful responses to historical challenges.

De Leon's legacy could be attributed not only to his extensive artistic output but also to his capacity, for example, to appropriate Western musical idioms. Appropriation of Western idioms did not make him less national- 
istic. Appropriation does not only meet the formalistic component of art for art's sake. Together with his fellow musicians and artists, appropriation became the means to manifest in their works their authentic desire for a truly Filipino nation. They aligned their individual efforts to building national sensibility through their art.

\section{Literature}

In literature, De Leon consciously located his artistic ideology in his article, "Poetry, Music and Social Consciousness." He juxtaposed Filipino artists from this side of the continent, such as Pedro Gatmaitan, Benigno Ramos, Lope K. Santos, Julian Cruz Balmaceda, Patricio Mariano, and Amado V. Hernandez with poets from the West like Yeats, Blake, Auden, and Arnold, giving testimony to the fact that art can function as a social conscience without forfeiting intrinsic aesthetic considerations. His list included the poems of Epifanio San Juan, Jr., Florentino Daus, Jolico Cuadra, Serafin Lanot, R. Zulueta da Costa, and Ricaredo Demetillo. ${ }^{1}$ Toward the 1930s, nationalism in Philippine literature was intense. Much of the works were set to music. The Filipinos could not fight the much-advantaged Americans frontally; thus the struggle was continued or carried out through art forms, the musical arts included. Familiarity was a key word. De Leon, paraphrasing T.S. Eliot, wrote:

The music of poetry must be a music latent in the common speech of the poet's place... It is the magic of familiarity which must permeate the very soul of one's work if he should be attributed with a high degree of social consciousness and task himself with not only making his music familiar but also, the familiar meaningful (Poetry, Music and Social Consciousness).

\section{Visual Arts}

De Leon regularly hosted gatherings of visual artists such as Carlos "Botong" Francisco, H. R. Ocampo, Cesar Legaspi, Guillermo E. Tolentino, and Demetrio Diego to preview his work, Cry of Balintawak (played on the piano), and an on-the-spot painting session. Subsequent artistic works related to 
this theme followed with a group art exhibit-a direct synthesis of music, history, and the visual arts.

Since De Leon's early Peñaranda (Nueva Ecija) days, the town's environment nurtured him with rich folk and popular traditions like band music and the zarzuela, which he imbibed at an early age. He honed not just his musical skills but also his other interests like the literary and visual arts. He was a man rounded in the humanities. De Leon believed that only when his roots are in his native culture which then nurtures the aspirations peculiar to his people can the Filipino composer create authentic Filipino music. De Leon has consistently based his compositions on:

the essence of such folk traditions such as the balitaw, danza, kumintang, taguylaylay, dalit and kundiman. Hence, in all of his works, there is an unmistakable Filipino spirit, even when he uses Western instruments, techniques and genres . . . by appropriating practically all the serious musical genres, including opera, he carried to the highest peak of fulfillment the task of incorporating such folk and traditional materials, termed here as Filipinization, with 'serious' classical Western music traditions auspiciously begun by Dr. Francisco Santiago, Nicanor Abelardo, Juan Hernandez, and Antonio Molina. No other Filipino composer was more thorough going in carrying out this task (Beltran 114).

\section{Music}

De Leon, together with the Creative Nationalist Lucio San Pedro, continued the nationalist tradition espoused by their mentors Santiago, Abelardo, Molina, and Hernandez and filled in the gaps between mimicry (blind utilization of folk materials) and appropriation (adoption of Western forms and expressions), with an extension to shades of early modernism.

By the 1930s, liturgical music, on which Philippine musical traditions of the previous centuries were anchored, had waned together with the vestiges of the Spanish Empire. During the period of Spanish colonization, "music was utilized as an attractive cultural ritual and social practice, which was adapted by the religious. It was likewise utilized for assimilation with the adoption of pre-existing rituals and 'Hispanizing' them to fit Christian rituals" (Irving 111). A point of view was that Christian rituals were Filipinized. Looking at 
De Leon's subsequent efforts, Western classical music, therefore, could be Filipinized without prejudice to its being foreign.

Para-liturgical music, on the other hand, particularly that of the indigenous lowland Christian traditions (subli, salubong, and so on) sustained, if not regained, its popularity for the simple reason that the practices were widespread, popular, and accessible. Culturally, the practices were deeply rooted in folk Catholic practice and anyone could participate in the tradition. Walls y Merino was critical that these musical practices were vestiges of Spanish culture. $^{2}$

The grand traditions of the opera and classical music, like the symphony, remained popular and must have been a cultural practice widely accessible and not limited to the ilustrado class. The house concerts or tertulia remained at the turn of the century, mostly as a social ritual, for entertainment.

What was new and explored as "academic" art; the media of the various arts became a cultural concern in the search for a deeper value, a raison d'être. This formal aspect in music instruction paved the way for introspection on the direction Filipino music was taking and how its expression, utilizing the conventions of classical music, could proliferate and be accessible.

One prominent genre prevalent then was band music. The narrative of the huge success of the Philippine Constabulary (PC) Band must have left an imprint on the young De Leon (Talusan 2004). He could not have missed such a narrative from the town maestro, particularly that of meeting a retired PC Band member, Potenciano del Rosario, who was at one time conductor of their band. It is a narrative about Filipino musicians achieving a level of artistry equaling, if not surpassing, that of their American counterpart (Osit 35).

Although the PC Band has been historically assessed as one of the most successful products of the United States policy of "benevolent assimilation," it cannot be denied that the PC Band propagated a musical practice that nurtured and impacted awareness on a national level. The roster of members of the PC Band illustrates a long familial lineage of musicians up to the present. 
Again, the time frame surrounding the 1930s abounds with socio-political underpinnings focused on cultural nationalism. Although responses were geared towards national implication such as national cultural policies, the means to realize the much-desired assertions in music were slow and tedious. With reference to local and microhistory, the dissemination and accessibility of compositions were limited to local audiences despite the advent of radio broadcasting. Sustaining positive reception continued amidst a fluid and volatile shift in musical tastes. National Artist for music Ramon P. Santos, in hindsight, wrote:

all-important works were either based on a Filipino folk melody or bore quotations from such as thematic materials. However critical, a lack of a much deeper perception of native musics ${ }^{3}$ in relation to their specific cultural and social environments as well as their functional and linguistic context produced a mostly peripheral view of their musical significance in the compositions, except as structural or thematic materials . . .It was only Nicanor Abelardo who may have hinted at exploring more deeply the "nativist soul" embedded not only in the melodies but also in the forms and modal constructs of the traditional materials; e.g., comintang, awit, etc. (136).

Santos was referring to the isolation of music from its larger use in Filipino cultural practices, especially indigenous music and orally-passed practices that have sonic components (e.g., rituals, rites of passage, festivities).

Nevertheless, "nationalism and indigenization provided the principal motivation in the campaign to filipinize music production in the country" (Santos 136). Santos spoke in general terms of methods of composition, referring to Abelardo as an exception. Abelardo and his contemporaries were the first generation of what could be called formally-trained musicians in the context of the establishment of the UP Conservatory of Music.

Regarding the pioneering efforts of nationalist composers, Santos mentioned $^{4}$ that the nationalist fervor in music could have been stimulated by the lecture "Filipino Musical Instruments and Airs of Long Ago" delivered by Justice Norberto Romualdez in the 1930s. ${ }^{5}$ Abelardo, together with Francisco Santiago and their other contemporaries, were mentioned because 
they were pioneers in the so-called "academized" art as contrasted with folk or traditional art. To bridge the two polarities, between 1931 and 1934, then University of the Philippines President Jorge Bocobo commissioned the collation of folk traditions and encoding them into a notation as references for future re-creation. He wrote:

It is hoped by this means to preserve this artistic inheritance of our people and to have the same become the foundation of future musical compositions that will reflect credit to the country .... As the years lapse and more facilities and better opportunities are given for the writing of original compositions inspired by these Filipino folksongs. In this way, the Filipino people may contribute to the musical art of the world (13).

It was such a significant effort to encode these oral traditions, which included 238 folk dances and 189 folksongs (Bocobo 13).

Like pioneering mentors such as Nicanor Abelardo, Lucio San Pedro (1913-2002) and others, Felipe P. De Leon stands side by side with the other stalwarts of Filipino nationalist composers. Taking up where Abelardo left off with his demise in 1934, Antonino Buenaventura (1904-1988), together with another UP mentor Hilarion Rubio (1902-1985) continued Abelardo's tutelage espousing musical nationalism. Buenaventura, who participated in the commissioned project of collating folk materials, imparted to his students his ardent passion for the utilization of folk materials that they did extensive research on.

San Pedro's Julliard School of Music years, on the other hand, proved enriching in defining his nationalist philosophy expressed in his symphonic works-his Suite Pastorale of which "Sa Ugoy ng Duyan” was a part of. It was for this latter melody that the late National Artist Levi Celerio shall subsequently write some fitting lyrics. Another of his monumental symphonic work is "Lahing Kayumanggi." Like San Pedro, De Leon explored the much expansive symphonic medium incorporating Filipino idioms into this largely European tradition.

Picking up the cudgels of pioneer nationalist musicians, Eliseo Pajaro (1915-1984) and De Leon, who were contemporaries, went into diverse 
paths as composers. Pajaro went deep into further exploring currents in modernism most likely acquired in his studies at Eastman School in Rochester, New York. De Leon, on the other hand, went outward expanding his vocabulary of folk idioms and practices, incorporating them further in his craft. All these composers echoed what Pajaro wrote with much concern that:

the Filipino composer should lead his people in developing a feeling of national consciousness and pride. He should likewise utilize the potentialities and richness of his country's musical resources, his heritage, history and tradition that it may become the composite voice of his people in its quest for a national music identity (3).

Another urgent concern that Pajaro raised was that one could not find anything Filipino in his music,

having been under foreign domination for many centuries ... that almost all of the music our people have been exposed to is borrowed music, whether on television, radio or in the concert halls. Our children have been taught from early childhood to sing foreign songs and to play foreign pieces. Is it any wonder then that our young people have become alienated from the cultural traditions of their country? (3)

He continued, "[m] usic from such amalgamation of influences since the Spanish colonial era and the prevalent sense of alienation of young people from Philippine cultural traditions call for a review of the music education system" (3).

In fact, Pajaro came short of saying that one is challenged at identifying the Filipino in prevalent musical practices. This concern seemed to be common in the other artistic endeavors as well. Versed in the vernacular, familiar with the power of symbols visual and ideal, and a witness to historical challenges and opportunities, De Leon produced an enormous output filling in the vacuum engulfing music's demand to answer this concern. His answer came with the use of Western classical music conventions but not toward "modernism" as Pajaro did. 
Santos' perspective, as mentioned earlier, regarding the lack of a much deeper perception of native music in relation to their specific cultural and social environments, except as structural or thematic materials, must be halftrue. Much of the social context associated with the so-called "native airs" (a much larger and encompassing term covering folk and popular tunes) are very distinct from the "indigenous." Indigenous practices are ethno-linguistically bound whereas "native airs" have a wider scope. There is a huge gap between the two and the indigenous; all these comprise Philippine music.

De Leon never got deeper into the musicological underpinnings of his materials, which explains Santos' assessment on musical materials-that "their functional and linguistic context produced a mostly peripheral view of their musical significance in the compositions" (45). He was, however, very much aware of the potential of music as a mode of expressing nationalist sentiment.

Regarding theatrical works, for example, La Tagala (1910) Tanda de Valses from the zarzuela Filipinas para los Filipinos was a much-performed Filipino overture until the '80s. Jose Estella utilized the waltz with a Filipino flavor eliciting much popular appeal. The song, “Ang Maya," for example, besides showing virtuosic prowess from the singer, is a metaphor of the nation caged like the bird maya calling for self-rule. Political undertones, like satire, were once more utilized. One could also recall M.H. Del Pilar's (1850-1896) satire Dasalan at Tocsohan (1888), written for La Solidaridad.

Theatrical presentations where music was a dominant component were prevalent. From 1900 to the 1940s, the sarswela (zarzuela) ${ }^{6}$ like Dalagang Bukid (1919) by Hermogenes Ilagan and Leon Ignacio was popular. Santos wrote:

In general, dramas and sarswelas represent a significant development if only because they pioneered in a more realistic portrayal of Filipino life. Unlike the colonial plays, these dramas and sarswelas trained their sights on current issues ... although their dramatic resolutions were to a fault simplistic (26).

De Leon was not known to be a zarzuela composer although he composed a few in this genre. He later discontinued writing in the idiom of the zarzuela 
and explored the larger genre of the full-scale opera. Arias and the incorporation the recitatives were novel in Filipino works then, an appropriation from the ever-popular European operas regularly presented then.

In formalist terms, the musical components of the zarzuela are still tied to something written by the Spaniards in a sense that these are song forms in the European convention. Subsequently, to indigenize these forms, Filipinos started to perform and eventually compose the sarswela, incorporating Filipino idioms in the native literary and musical expressions with its distinct melodic contour, harmonic progression, and utilization of adapted rhythmic elements (as synthesized in the various writings of Antonio Molina on Philippine rhythms); and of Santiago and Abelardo's melodic and harmonic elements as well. The text-music relation might appear to have been "simplistic" in literary terms, but as in the previous centuries, the resulting incorporation heightened the music's appeal to Filipino sensibilities.

\section{De Leon as Cultural Chronicler}

A significant side of De Leon is his sense of history through his chronicles of musical events and his various views and perceptions of the Filipino audience's reception. It was through his chronicles that one reader could somehow grasp the spirit of the era. Since his early years, the then 24-year-old De Leon was part of the university's publication, The Philippine Collegian, not only as a contributor from the Conservatory of Music, but also as part of a Department staff assigned to write in the vernacular (De Leon 8). By 1938, he wrote extensively for his Art and Music column in the Collegian. The publication had its first Tagalog section in 1928 also upon the initiative of Jorge Bocobo.

In his columns, De Leon was generous in his praises but critical in his assessments. He guided his readers with explanations, especially the laymen who were unfamiliar with the music jargon. He educated them in music history and updated them on the latest trends in music performances and practices overseas.

Chronicling included composing for the theater. De Leon wrote ten sarswela. His first, "At Sa Wakas" was written in 1928 and his last "Malapit 
na ang Umaga” in 1942. However, after a gap of a little over a decade, he tackled the genre of opera.

The formation of his artistic philosophy, his humanism, and the road map he would subsequently take, are reflected in his writings as a 26-year-old man idealizing on the power of the musical craft:

Music is an important intellectual and sociological force and there is no other force which can socialize, energize and guide the emotions of masses from childhood to maturity than good music (The Philippine Collegian, September 1938).

He was vocal in asserting the need to place music education in a "very distinct place" in the public education system. He was on the defensive over the prevailing questions about the need to teach music to people never intending to become musicians, responding that,

[i]f this is done, the efforts employed by our leading educators in developing those mental habits, traits and characters, and social and civic ideals which contribute to the development of an industrious, useful, happy, and desirable citizenship will be minimized to a better and desirable result (The Philippine Collegian, November 1938).

It was a call, a vigorous campaign to utilize the fine arts on an equal footing with other disciplines for nation building.

It was also around this time that De Leon, using the pseudonym Fedella, took the opportunity in presenting articles pertaining to music. It was the first time, he acknowledged, that he wrote notes about the UP School of Fine Arts, of which the Music Department was once part. He rhapsodized on the Filipino kundiman, its form, on Epifanio de los Santos' theory on its etymology, kung hindi man (if not meant to be). He wrote about the sonata and opera, defining them for lay persons and juxtaposing them, using Filipino examples, like "Nasaan ka Irog," as well as Rossini's "Poet and Peasant Overture." He was all praises for Francisco Santiago's Remembrance, emphasizing its recognition by the Chicago Daily News which awarded him a prize in the competition they sponsored. He even wrote about decorum 
for concertgoers and updates on society events (De Leon, 1938). These and many more demonstrate the diverse scope of his chronicles.

Worth noting are his significant ideas and campaign on the use of the national language and on Rizal's heroism. He regularly posed the question, "What is national music?" and lectured on the merits of Filipino music (The Philippine Collegian, 1938). With President Quezon's proclamation encouraging the use of the national language, parallel assertions were made by De Leon about music:

As local vernacular writers and noted scholars are now very busy studying the aspects of the Tagalog language and how it can be taught to the different institutions, our leading musicians and composers on the other hand are leaving no stone unturned in creating a music that is distinctly Philippine from the vast treasures of folk-songs of our country by President Bocobo's committee assigned for this purpose. Pioneers in this connection are Dr. Francisco Santiago, director of the U.P. Conservatory of Music, Lt. Antonino Buenaventura, Prof. Juan Hernandez. Others that can be mentioned are Prof. Hilarion F. Rubio, Prof. Ramon Tapales, Prof. Jose Estella, Prof. Bonifacio Abdon, who also employ native airs as themes to their compositions, thereby nationalizing our own music and making it easily recognizable from the music of other countries (The Philippine Collegian, September 1938).

One subsequent implication was the widespread utilization of folksongs.

\section{Zeitgeist and Reconstructing History}

Reconstructing zeitgeist considers the tensions that exist between music histories (the practice of music, such as performances) vis-à-vis music theories (the concept or constructs of tone engineering in terms of context). The central tenet of renowned cultural anthropologist Clifford Geertz is that

in order to understand individual human action we need to interpret the cultural context from which they arise. And in applying it to musicology, Tomlinson reveals a central tenet that musical art works are the codifications or inscribed reflections of human creative actions, and hence should be understood through the similar interpretation of cultural context (2). 
However, this author is cautious not to cross too excessively the boundaries towards semiotics and sustain "traditional" historical narrative on musical practices. The historian's task is to make sense of the rational and irrational actions, out of the internal and external circumstances and the winds of changes that coagulates everything:

Society is not a unity but an amalgam of interlocking spheres: what is context for one is focus for another. Tomlinson suggests that the process by which music historians search for context is 'a reciprocal one in which art work illuminates the context as the context illuminates the art work'; but he also points out that this process must work within the inherent disorder of culture (Tomlinson 356-357).

Political eras shall just serve as chronological markers or time frame references. Family history and microhistory attached to institutional and local history, as the case may be for De Leon, hold potential in the bricklaying of history. Personal histories, intertwined with narratives of local, institutional, and national scope strengthen any study toward the author's goals.

Extant and majority of the prevailing writings as well as chronicles in Philippine music history, particularly that of the musical performance art, without asserting general prejudices into the canons of previous writings, tend to look at musicians and musical practices in relation to their epoch. These musicians and their practices are also looked at as isolated or interesting incidents and peculiarities of amazing divas and virtuosos, ingenuous composers and their "popular" songs. It is therefore a task of music historians to collate these facts into a perceivable whole, a Gestalt-the sum of the parts is more than the whole. To simply narrate things, interpret without distortion, exaggeration, deletion, or omission, is enough for the reader to understand and not tilt towards extreme value judgment.

Reception history, as described by Dahlhaus, is a significant component in reconstructing zeitgeist (150). Much challenge, however, lies in its attached conclusion, which tends to border on grey areas that would eventually require much validation. For example, it entails a compendium of what 
the press has written. Where did the initiatives come from? Who were the target audiences and listeners if they were a radio broadcast? How many people came (to the concert) and from what orientation? A parallel between political and cultural or social history could utilize some connections, direct or otherwise, as well as contextualization. All these questions, without claims of comprehensiveness, continuously seek answers in the reconstruction of the zeitgeist.

It is worth mentioning here Ernest Gellner's conceptualization of the role of culture in nationalism:

[C] ulture replaces structure as the source of a person's identity in the modern world ... In the modern world, people are loyal "not to a monarch or a land or faith ... but to a culture. This is the unifying national culture also orients people toward a polity. This goal is of course based on the assumption that every nation is entitled to rule itself. The national culture, then, both fuses the populace into a whole and delimits who belongs, in many senses it is the actual basis of the imagined community (169).

To put the above passage in Philippine context, the structure of musical eras as represented in the popular genres (e.g., church music, secular theatre music, revolutionary music) are, with the homogenizing goal and subsequent effect, both intended and unintended, of the American colonization, set the Filipino into a search for refuge to protect his identity amid changes brought about by an imposition of a new cultural perspective. Again, music, not only as an art form but also as a cultural practice, has been a constant refuge, whether as an escape or coping mechanism, whether for leisure or for other functions.

After the 1930s, De Leon's other efforts and campaign are manifest in his subsequent post-war radio programs, illustrating efforts to protect his Filipino identity. His radio programs were broadcast to a wide audience in the Philippines from Batac to Davao and many other places reached by radio. ${ }^{7}$ When De Leon wrote or talked about music, he was fully aware of his nationalist tone. Generally, De Leon, along with his mentors and other contemporaries, created and campaigned for the recognition of Filipino- 
ness. Consequently, they, as nationalist composers, applied culture with their claims that their art represented their nation's inherent values, character, and cultural aspirations. They created not just art but also social products with artistic as well as political goals. De Leon's works are rich with allusions to either significant historical events or personal sentiments on nationhood. This confirms what Benjamin Curtis articulated:

to be genuinely national, culture must be monopolistic, as the exclusive, unified high culture associated with a particular society and polity. It is assumed to belong to all members of that society and polity . . . they are concerned with creating that culture, with weaving the web of meaning that unites the (sometimes splintered) populace. Nationalist artists are typically most concerned with making it a 'high culture'. Though they do not reject the need for the 'lower' elements of a national culture, they attach the most value to the higher realm for reasons of prestige and for its supposed power to educate the populace (25).

This explains the campaign of De Leon in all forms of media. The mass distribution of American music, for example, was considered an affront to Filipino values. Philippine music, as well as classical music, which were much cherished, faced a perceived threat. Nicanor Tiongson, an authority in the Filipino zarzuela, said:

In the field of theater, the Americans introduced two important types to the Philippines: the bodabil or stage shows and the so-called "legitimate" plays . . . these shows transport audiences into American dreamland through the songs, dances, comedy skits and production numbers on stage . . . Finally, because of their proven effectivity in Americanizing Filipinos, bodabil and "legitimate" plays certainly help make more palatable to the Filipino America's continuing presence in the Philippines ... On the other hand, although the Filipino was Americanized in thought, taste and temper by these plays, so was he equipped by them with many, new dramatic theories and styles that opened new avenues for growth and expanded the horizons for theatrical expression of Filipino playwrights, directors, actors, designers and stage managers (Tuklas Sining 85-86). 
The prevalent fear among nationalists and "high art" musicians was accurately described as the "worst prediction of a commodified and commercialized culture, with differences flattened into global uniformity as a bad western pop universal superseding Adorno's good classical version. Such a view of homogenized and commodified culture has however been contested as arguing for oppositional popular possibilities; Shuker suggests that to consider the popular music audience "a mass of passive recipients is totally at variance with contemporary audience studies" (Leyshton et al., 428). Popular music, defined here as "music that was most popular in measurable terms... a continuation of nineteenth-century popular music, which was disseminated and consumed in the form of sheet music..." (Hamm et al., 126). Commodification and commercialization, music's existence solely for entertainment, were anxieties prevalent among academics who were likewise nationalists like De Leon. Sustaining the prestige of "Filipinized" classical music remained an imperative.

De Leon's thoughts amplified his efforts for Filipino compositions to be popular. Efforts were exerted for his craft to be popular, in the realm of folk-related tradition, enough for the ordinary, everyday Filipino to appreciate and participate in. In an age of a great paradigm shift-politically, socially, economically, and culturally-manifestations in musical expressions have a place, too. In an era when postmodernism was not yet a familiar theory, De Leon must have been anticipating this place in the spectrum of historical narrative through his music since postmodernism places "the artist within a socio-economic and political system with its own overriding reality, which subsumes the individual. With its advent, the concept of the avantgarde comes to a halt. Modernism and avant-gardism have, of course, been categorized as of the same ilk, as they both refer to art as highly specialized, quite hard to understand, and only a small segment of the audience knowledgeable about modern history and theory can only understand. Pop art, on the other hand, is comprehensible to the ordinary people who enjoy reading comic books" (Kurtz 13-14).

In terms of musical output, the De Leon's exploration of several genres can be classified as follows: major works like his two operas Noli me Tangere 
(1953) and El Filibusterismo (1970), orchestral works, compositions for bands, theater works (zarzuela), religious and secular hymns-including his popular Christmas carols like Payapang Daigdig (1946) and Pasko na Naman (1965)-marches, chamber music, and countless songs. His works constitute as musical representations or frames of references, text from which the composer's individual ideas and collective experiences could be extracted, interpolated, and interpreted.

De Leon's actions in the context of Philippine history also confirm what William Weber posited as a fresh perspective on the "rethinking of Zeitgeist and the place of music within it":

On the one hand, historians must come to recognize music as a vital aspect of general history; and that the "two complementary points emerge from the rethinking of zeitgeist advanced here and the place of music within it.

On the other, music-indeed, any art-must be

approached in terms of its own traditions. We can thus see that, since music held a central place in public life, it can serve as a useful vehicle through which to gain an understanding of class structure, the political community, social values, and ways of life. That can be achieved, however, only by working within an awareness of the social structures and intellectual practices particular to musical culture (though not necessarily by intention) toward building bridges with historians (Weber 344-345).

The travails of De Leon's life journey were like his shadow cast by the light of Philippine historical experiences. He assumed the role of both the musician and the historical character of the musician. 


\section{Notes}

1. Felipe Padilla De Leon. Poetry, Music and Social Consciousness. TS, composer's personal copy.

2. See Manuel Walls y Merino, Popular Music of the Philippines.

3. The German language has a plural form for music and the plural form of English pertains in this usage pertains to the diverse contexts of cultural expressions.

4. Renato B. Lucas, interview with Dr. Ramon P. Santos, 12 Sept. 2014.

5. Lecture delivered at the Conservatory of Music, University of the Philippines on 25 Nov. 1931.

6. The word sarswela is an indigenized variation of a form of Spanish musical theater called the zarzuela.

7. Digital copies of the radio programs are with the University of the Philippines Center for Ethnomusicology. 


\section{Works Cited}

Agoncillo, Teodoro. "How Nationalism Fared Under America." Filipino Heritage: The Making of a Nation, vol. 9, Lahing Pilipino, 1978.

Beltran, Herminio Jr., editor. The National Artists of the Philippines. Cultural Center of the Philippines, National Commission for Culture and the Arts and Anvil Publications, 1998.

Constantino, Renato. "Veneration Without Understanding." Third National Rizal Day Lecture, 30 Dec. 1969.

Curtis, Benjamin W. Music Makes the Nation: Nationalist Composers and Nation Building in the Nineteenth-Century Europe. Cambria P, 2008.

Dahlhaus, Carl. Foundations of Music History. Translated by J.B. Robertson, Cambridge UP, 1983.

De Leon, Felipe Padilla. Poetry, Music and Social Consciousness. TS personal copy of the composer.

---. The Philippine Collegian, 7 Sept. 1936.

---. "Music and Arts." The Philippine Collegian, 15 Sept. 1938.

---. The Philippine Collegian, 12, 26 Sept; 24 Oct.; 14 Nov. 1938.

---. The Philippine Collegian, 30 Nov. 1938.

Gellner, Ernest. Nations and Nationalism. Blackwell, 2006.

Hamm, Charles, et al. "The Acculturation of Musical Styles." Contemporary Music and Music Cultures. Prentice-Hall, Inc., 1975.

Hila, Antonio C. Music in History, History in Music. University of Santo Tomas Publishing House, 2004.

Irving, D.R.M. Colonial Counterpoint Colonial Counterpoint: Music in Early Modern Manila. Oxford UP, 2010.

Kurtz, Bruce D. Contemporary Art, 1965-1990. Prentice Hall Inc., 1992.

Leyshton, Andrew, et al. The Place of Music. Transactions of the Institute of British Geographers, 20, 1995.

Mirano, Elena Rivera, editor. The Life and Works of Marcelo Adonay. U of the Philippines P, 2009.

Mojares, Resil. "The Formation of Philippine Nationalism under US Colonial Rule." Philippine Quarterly of Culture and Society, vol. 34, no. 1, 2006, pp. 11-32.

Molina, Antonio. Philippine Ethnographic Rhythms: A Brief Analytical Survey of the Rhythmical Patterns as They Appear in Some of the Most Important Types of Philippine Music of Today. University of the Philippines Music Library, 1966.

Navarro, Raul. Kolonyal na Patakaran at ang Nagbabagong Kamalayang Filipino: Musika sa Publikong Paaralan sa Pilipinas, 1898-1935. Ateneo de Manila UP, 2007.

Ortiz, Ma. Aurora R., et al. Art: Perception and Appreciation. University of the East, 1976. 
Osit, Jorge B. Felipe P. De Leon: A Filipino Nationalist. Jorge B. Osit, 1984.

Pájaro, Eliseo M. "The Filipino Composer and His Role in the New Society."

Professorial Chair Lecture Monograph No. 13. U of the Philippines P, 1976.

Patajo-Legasto, Priscelina. Anacbanua ideology and the Pangasinan Zarzuela during the

Philippines Revolution and Its Aftermath. U of the Philippines P, 2000.

Romualdez, Norberto. "Filipino Musical Instruments and Airs of Long Ago." 25

Nov. 1931, Conservatory of Music, University of the Philippines. Lecture.

Sachs, Curt. The Commonwealth of Art: Style in the Fine Arts, Music and the Dance.

Norton and Company Inc., 1946.

Samson, Helen F. Die zeitgenössische Kunstmusik der Philippinen im Spannungsfeld

zwischen nationalem Erbe und europäsischem Einfluß. Gustav Bosse Verlag, 1989.

Santos, Ramón. Laon-laan: Perspectives in Transmission and Pedagogy of

Musical Traditions in Post-colonial Southeast Asia. UST Publishing House, 2012.

---. Personal interview, 12 Sept. 2014.

Talusan, Mary. "Music, Race, and Imperialism: The Philippine Constabulary Band at the 1904 St. Louis World's Fair.” Philippine Studies: Historical and Ethnographic Viewpoints, vol. 52, no. 4, 2004, pp. 499-526.

Tiongson, Nicanor G., editor. Tuklas Sining: Essays on Philippine Art. Sentrong Pangkultura ng Pilipinas, 1991.

---. Sarsuwela. ASEAN Committee on Culture and Information, 1986.

Walls y Merino, Manuel. Popular Music of the Philippines. Madrid: Libreria de Fernando Pe, Carrero de San Jeronimo, Num. 2, 1892, translated by Maria Delia T. Matibag. Manila, National Historical Institute, 1980.

Weber, William. "Beyond Zeitgeist: Recent Work in Music History." The Journal of Modern History, vol. 66, no. 2, June 1994, pp. 321-345. 